\title{
Analysis of Online Learning Readiness Level at Universitas Nahdlatul Ulama Surabaya (UNUSA)
}

\author{
Endang Sulistiyani ${ }^{1 *}$, Rizqi Putri Nourma Budiarti ${ }^{2}$, Muhammad Aidir Rafly ${ }^{3}$ \\ 1,2,3 Universitas Nahdlatul Ulama Surabaya \\ J1. Jemursari No 51-57, Surabaya, 60237, Indonesia \\ *sulistiyani.endang@anusa.ac.id
}

\section{ARTICLE INFO}

Article history:

Received 31 October 2020

Accepted 22 January 2021

Published 31 January 2021

\begin{abstract}
IN ENGLISH
Since a few years ago, blended learning has been implemented by UNUSA. However, until now, the implementation is still not optimal. Various obstacles, such as network access, availability of devices, and unclear rules in implementing online learning, still occur. Readiness analysis is one of the critical success in online learning implementation. The main objective of this research is to conduct online learning readiness studies at UNUSA. This research was carried out in three main stages: the preparation of measurement instruments, data collection, and analysis of readiness level. The method used is descriptive research method with quantitative and qualitative approaches. The Seakow \& Samson e-learning readiness model with five dimensions of readiness, namely policy, technology, financial, human resource, and infrastructure, is used in this study. The result of this study shows that that UNUSA's level of readiness in implementing online learning is in the Ready category, requiring improvement to implement it with a readiness score of 3.68. The dimension with the highest score is technology, which is 3.84 . Meanwhile, infrastructure and policy scored 3.77 and 3.72 , respectively. The human resources dimension has a readiness score of 3.6. In contrast, the dimension with the lowest score is the financial dimension.
\end{abstract}

Keywords:

Online learning, readiness

level, UNUSA

\section{Introduction}

In the Industry 4.0 era, online learning in higher education is a necessity. This is in accordance with what was conveyed by the Ministry of Research, Technology, and Higher Education that one of the Tri Dharma Perguruan Tinggi paradigms that must be harmonized is online learning. The implementation of online learning is referred to as a higher education strategy in responding to the challenges of industrial revolution 4.0. This recommendation refers to the Regulation of the Minister of Research, Technology and Higher Education Number 51 of 2018 [1]. Online learning can be defined as two things, namely as part of distance education or part of conventional education (face to face). Learning that combines online, and face-to-face learning is known as blended / hybrid learning. Meanwhile, learning that most or all teaching materials are delivered online, without face-to-face portions at all, is referred to as fully online [1].

Nahdlatul Ulama University Surabaya (UNUSA) is one of the private universities in Surabaya. Since a few years ago, online learning has been implemented by UNUSA. The type of learning applied in blended/hybrid learning. However, the Covid-19 Pandemic, which began to hit in March forced UNUSA to fully implement online learning. This resulted in a change in the form of lectures, which was originally only part of the online learning portion and was now limited to being completely online [2]. However, the facts show that the realization of the implementation of online learning at UNUSA from March $1 \mathrm{st}^{\text {st }}$ May 18th ${ }^{\text {th }} 2020$ is still 87.7\% [3]. Meanwhile, from the student side, as stated in the press release of one of the Student-Faculty Board, several notes were obtained on the policies and 
implementation of online lectures. These records include the fulfillment of facilities for teaching and learning activities and the form of teaching and learning activities itself [4]. In fact, based on the Vice-Rector in the academic field, it was revealed that blended learning that has been implemented so far is one of the steps to prepare distance learning in the next few years [5].

Chapnick and Aydm in [6] concluded that an organization must be careful in the process of adopting online learning. Research conducted by Emma King in 2014 [7] states that the adoption of online learning in a college is not easy. Various challenges arise, ranging from a readiness for infrastructure needs and awareness of technology's benefits in the learning process. Research related to online learning states that one of the keys to success in implementing online learning is readiness study [8], [9]. One of the things recommended based on the results of several studies on this condition is to conduct a readiness study for the application of online learning [6], [8], [10], [11]. Readiness evaluation is needed as a starting point in evaluating the implementation of education in the digital era [12]. This evaluation aims to reveal areas that are still not ready and need improvement and provide an overview of the organization's overall readiness for the online learning implementation [6], [13].

In order to conduct an effective readiness evaluation, an online learning readiness model is needed as a measurement instrument [14], [15]. The implementation of online learning requires several components that must be prepared. According to Succi in [16], it is stated that human resources, organizations, and assets are the main keys to implementing online learning. This is in line with what Aydm [17] revealed that the success of e-learning requires the provision of infrastructure, technology, human resources, organizational culture, and leadership. Research conducted by Borotis in 2008 [14] added another component, namely finance, as an element in the success of online learning. In his research, Saeko in 2011 [8] revealed that online learning readiness dimensions include policy, technology, human resources, infrastructure, and finance. This model is sufficient to cover some of the components needed to make online learning successful that have previously been revealed by other researchers.

Therefore, based on the current conditions of implementing online learning at UNUSA and the importance of readiness studies, the main objective of this research is to conduct online learning readiness studies at UNUSA. It is hoped that the results of this research can be used as an initial evaluation to prepare for online learning continually. In addition to obtaining a readiness index from each dimension and as a whole, this research will provide an overview of the areas, both those that are ready and those that are still weak and need improvement. Thus, UNUSA can determine strategies and policies that are more appropriate and targeted according to the results of the readiness evaluation. Given that online learning will be fully carried out in the next few years in the context of carrying out distance learning. Specifically, the research questions that will be answered in this study are:

1. How is UNUSA's online learning readiness level?

2. What are the readiness dimensions that need to be improved in online learning implementation?.

\section{Related Work}

\subsection{Online Learning Readiness}

Online learning can be defined as a flexible learning experience that makes use of ICT and can be accessed anytime, anywhere, by anyone [1], [6], [9], [14]. This learning model can be used in distance education and conventional education (face to face). The explanation of online learning for each education is as follows [1].

a. Part of the implementation of the Distance Education Study Program, meaning that there may be a limited face-to-face portion in the form of tutorials (for conducting practicums, etc.).

b. Part of the implementation of the Face-to-Face Study Program, meaning that there may be an online portion (for $<50 \%$ of the number of courses in the study program), depending on the policy of the higher education leader supported, by the higher education senate.

Readiness is a condition that is owned by both individuals and organizations in preparing themselves both mentally and physically to achieve the desired goals [18]. [18]. Online learning readiness can be defined as physical and mental preparation for action or online learning experience [8], [14] [19]. It is essential to understand that readiness is not a one-time action but an ongoing process. A readiness assessment is very important for the successful implementation of online learning that is in line with organizational needs. Not only that, but past failures should also be analyzed to reduce the risk of online learning interventions [8].

\subsection{Dimension of Online Learning Readiness}

Online learning isn't just about technology [17]. This is because there are many related elements in the learning process, starting from teachers, students, administration, and policy. Borotic's model was adopted in the study [8] defines that the dimensions of online learning readiness include five things, namely policy, technology, financial, human resources, and infrastructure. The policy dimension (policy) relates to the availability of regulations, vision and mission, long-term plans, organizational culture, leadership support, and online learning evaluation mechanisms. In addition, this regulation must also be in line with the goals of higher education. The clarity of this regulation will be the basis, from planning to evaluation. This is the responsibility of the leader of the organization at all levels, both 
top, and management. Readiness on this dimension will clarify the alignment between the implementation of online learning and the overall organizational goals. Its existence will also reduce confusion and rejection from relevant stakeholders, given this dimension's nature as a legal basis [8]. The technology dimension focuses on the readiness of the organization in preparing media or tools for implementing online learning. The technology provided must be able to integrate existing learning business processes, from planning to evaluation [8]. The financial dimension refers to the preparation of costs for implementing online learning. This preparation includes the provision of subsidies or a transparent budgeting mechanism [8]. The infrastructure dimension refers to the provision of devices, including networking, hardware, and software [8]. The human resource dimension refers to competence and awareness of the benefits and importance of online learning. This dimension also considers the availability and design of the human resource support system [8].

\subsection{Previous Studies}

Previous studies that underlie this study are presented in Table 1. Based on previous research, it is known that the implementation of online learning is a must. However, in its application, there are various challenges. One of the keys to the successful implementation of online learning is conducting a readiness analysis. In order to conduct an effective readiness evaluation, an online learning readiness model is needed as a measurement instrument. The readiness model must be following the online learning component, which includes technical and non-technical matters.

Table 1- Previous Research

\begin{tabular}{lll}
\hline No & \multicolumn{1}{c}{ Title } & \multicolumn{1}{c}{ Result } \\
\hline $\mathbf{1}$ & $\begin{array}{l}\text { The Readiness Level of Implementation E- } \\
\text { Learning in Yogyakarta High Schools [6] }\end{array}$ & $\begin{array}{l}\text { An organization must be careful in the process } \\
\text { of adopting online learning }\end{array}$ \\
\hline $\mathbf{2}$ & $\begin{array}{l}\text { Exploring factors that influence adoption of e- } \\
\text { learning within higher education [7]. }\end{array}$ & $\begin{array}{l}\text { The adoption of online learning in a college is } \\
\text { not easy. Various challenges arise, ranging } \\
\text { from a readiness for infrastructure needs and } \\
\text { awareness of technology's benefits in the } \\
\text { learning process. }\end{array}$ \\
\hline $\mathbf{3} \quad \begin{array}{l}\text { Teachers Student'snt's view on e-learning } \\
\text { Readiness in Kuwait's Secondary Public Schools } \\
\text { [11]. }\end{array}$ & $\begin{array}{l}\text { One of the keys to success in implementing } \\
\text { online learning is readiness study }\end{array}$ \\
\hline $\begin{array}{l}\text { E-Learning Readiness Components: Key Issues } \\
\text { to Consider Before Adopting E-Learning } \\
\text { Interventions [14] }\end{array}$ & $\begin{array}{l}\text { An effective readiness evaluation, an online } \\
\text { learning readiness model, is needed as a } \\
\text { measurement instrument. the readiness model } \\
\text { must be in accordance with the online learning } \\
\text { component, which includes technical and non- } \\
\text { technical matters }\end{array}$ \\
\end{tabular}

\section{Research Method}

The method used in the readiness analysis is the descriptive research method with quantitative and qualitative approach. By definition, this study seeks to describe the readiness of universities in implementing online learning. To achieve the objectives, this research was carried out in three main stages (see Fig 1). First is the preparation of measurement instruments. The second is data collection. The last is an analysis of the level of readiness for online learning.
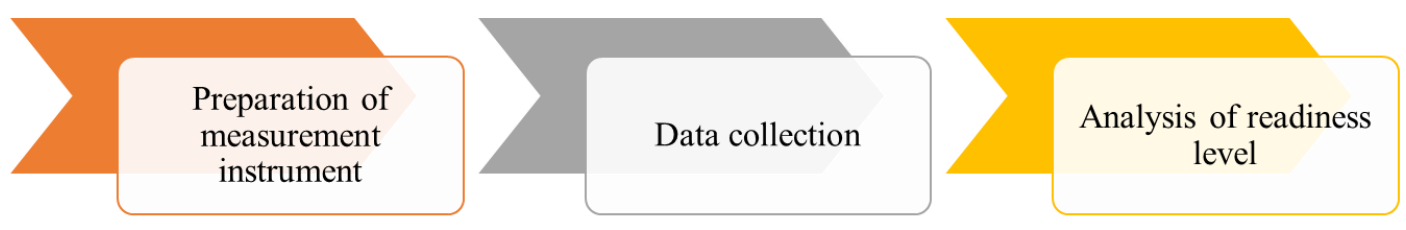

Fig. 1 Research Methodology

The preparation of a readiness measurement instrument is based on an online learning readiness model. The model used to measure readiness is the Seakow \& Samson e-learning readiness model [8]. Based on Seakow \& Samson 
[8], there are five dimensions of readiness, namely policy, technology, financial, human resource, and infrastructure. There are 21 questions based on the five dimensions of readiness. Each question will have five alternative answers, from one to five. The value one represents strongly disagree, and five represents strongly agree. Furthermore, the results of the questionnaire will be calculated on the average of respondents' answers for each dimension. The result will show a readiness score. The level of readiness for implementing online learning is seen from each dimension and as a whole.

In the second step, data collection using questionnaires and interviews. The questionnaire was distributed to lecturers and students via a google form. The number of respondents was 36 for lecturers and 196 for students. Meanwhile, structured interviews are used to obtain efforts made by UNUSA in implementing online learning from the management and technical aspects of technology provision. Interviews were conducted with university leaders as well as the IT team. The technique for selecting the two informants uses the purposive sampling technique, which is a sampling technique based on the consideration that focuses on a specific goal, not the representation of all populations.

Furthermore, the results of the questionnaire will be calculated on the average of respondents' answers for each dimension. The result will show a readiness score. The level of readiness for implementing online learning is seen from each dimension and as a whole. In this study, the index model taken from Aydin \& Tasci index [16] was used to categorize the level of readiness. The details of the readiness index are as follows:

1. Index $1-2.59$ is not ready, it requires a lot of preparation to implement e-learning.

2. Index 2,6 - 3,39 is not ready, it only requires preparation of a few aspects.

3. Index 3,4 - 4,19 is ready, requiring improvement to implement it.

4. Index of $4.2-5$ is on ready, indicating a good readiness to implement e-learning

Based on this index, it is known that an organization can be categorized as ready if it has a minimum index value of 3.4..

\section{Result and Discussion}

\subsection{Instrument Testing}

Validity and reliability tests were carried out to determine the accuracy and reliability of the questionnaire to be used as a measurement instrument. In this study, both tests were carried out using SPSS software. This validity test aims to determine and prove the validity level of an instrument used to collect data. An instrument is said to be valid if the questions on the questionnaire are able to show something that will be measured by the instrument on the questionnaire. Significance test is done by comparing result (Pearson correlation) with r-table. If r-count $>$ r-table and produces a positive value, the question item is declared valid. In this study, it is known that $\mathrm{n}$ (many samples) = 36 , $(\mathrm{df})=36-2=34$, then the significance level of 0.05 is 0.339 . The results of the validity test are presented in Table 2. Based on Table 2, it is known that the r-count of each item has a value greater than the rtable. In accordance with the existing rules, it can be concluded that this research questionnaire is valid to be used as a measurement instrument.

Table 2- Result of Validity Test

\begin{tabular}{|c|c|c|c|c|}
\hline No & Variable & Item Code & rCount & Result \\
\hline \multirow{9}{*}{1.} & \multirow{9}{*}{ Policy } & P1 & 0.634 & Valid \\
\hline & & $\mathrm{P} 2$ & 0.592 & Valid \\
\hline & & P3 & 0.558 & Valid \\
\hline & & $\mathrm{P} 4$ & 0.498 & Valid \\
\hline & & P5 & 0.551 & Valid \\
\hline & & P6 & 0.752 & Valid \\
\hline & & P7 & 0.734 & Valid \\
\hline & & P8 & 0.745 & Valid \\
\hline & & P9 & 0.620 & Valid \\
\hline \multirow{3}{*}{2.} & \multirow{3}{*}{ Human Resources } & HR1 & 0.761 & Valid \\
\hline & & HR2 & 0.405 & Valid \\
\hline & & HR3 & 0.472 & Valid \\
\hline \multirow{3}{*}{3.} & \multirow{3}{*}{ Infrastructure } & I1 & 0.794 & Valid \\
\hline & & $\mathrm{I} 2$ & 0.705 & Valid \\
\hline & & I3 & 0.834 & Valid \\
\hline \multirow{3}{*}{4.} & \multirow{3}{*}{ Technology } & $\mathrm{T} 1$ & 0.722 & Valid \\
\hline & & $\mathrm{T} 2$ & 0.725 & Valid \\
\hline & & T3 & 0.531 & Valid \\
\hline
\end{tabular}




\begin{tabular}{ccccc}
\hline No & Variable & Item Code & rCount & Result \\
\hline \multirow{3}{*}{ 5. } & \multirow{2}{*}{ Financial } & F1 & 0.597 & Valid \\
\cline { 3 - 5 } & & F2 & 0.652 & Valid \\
\cline { 3 - 5 } & & F3 & 0.742 & Valid \\
\hline
\end{tabular}

Meanwhile, the reliability test aims to determine the indicators on the instruments used in data collection are reliable or not. An indicator is declared reliable if the Cronbach's Alpha value shows a result greater than 0.60 . The reliability test results in Table 3 show that the Cronbach alpha value of each variable has a value greater than 0.60 . This means that all variables are declared reliable. Details of the value of each variable are presented in Table 3 .

Table 3- Result of Reliability Test

\begin{tabular}{cccl}
\hline No & Variable & Cronbach alpha & Result \\
\hline 1 & Policy & 0.854 & Reliable \\
\hline 2 & $\begin{array}{c}\text { Human } \\
\text { Resource }\end{array}$ & 0.732 & Reliable \\
\hline 3 & Infrastructure & 0.880 & Reliable \\
\hline 4 & Technology & 0.657 & Reliable \\
\hline 5 & Financial & 0.940 & Reliable \\
\hline
\end{tabular}

\subsection{Policy Dimension}

The policy dimension relates to organizational support in the organization's business [6]. Start from the preparation from the planning side, including long-term vision and plans. Management support such as leadership support, policy provision, evaluation mechanisms. Also included in this dimension is the online learning culture in the organization [20]. This dimension is very important to create conducive change. As concluded in the research conducted by Nur Azaliah that when an IT innovation is introduced in an organization, it will bring change. The organization must have a proper change management plan including clarity of policies, monitoring and evaluation mechanisms, and change sponsorship by the leader [20].The results of the questionnaire processing show the readiness score 4.17 from the lecturer's perspective. Meanwhile, from Student's perspective, the score readiness is 3.63. Details of the average score for each statement item, the readiness score, and the readiness index category for the policy dimension can be seen in Tables 4 and 5. Table 4 for the lecturer's perspective and Table 5 for the student perspective.

Table 4- Readiness level of Policy Dimension from the Lecturer Perspective

\begin{tabular}{|c|c|c|c|c|c|}
\hline Dimension & $\begin{array}{l}\text { Item } \\
\text { Code }\end{array}$ & Item Description & Value & Readiness Score & Readiness Index \\
\hline \multirow[t]{6}{*}{ Policy } & $\mathrm{P} 1$ & Vision & 4.19 & \multirow[t]{6}{*}{4.17} & \multirow{6}{*}{$\begin{array}{l}\text { Ready, requires } \\
\text { improvement to } \\
\text { implement it }\end{array}$} \\
\hline & $\mathrm{P} 2$ & Long term plan & 4.17 & & \\
\hline & P3 & Regulation & 4.14 & & \\
\hline & $\mathrm{P} 4$ & Management support & 4.61 & & \\
\hline & P5 & Organizational culture & 3.97 & & \\
\hline & $\begin{array}{l}\text { P6, P7, } \\
\text { P8, P9 }\end{array}$ & $\begin{array}{l}\text { Monitoring and } \\
\text { evaluation mechanisms }\end{array}$ & 3.99 & & \\
\hline
\end{tabular}

Based on Table 4, it is known that from a lecturer perspective the policy dimension has a readiness score of 4.17. This score makes the level of readiness of the policy dimension in the Ready category, requiring improvement to implement it. If we analyze deeply, this score is supported by all statement items for this dimension. All statement items also have a readiness score, which is included in the Ready category, requiring improvement to implement it. The highest scores were obtained for leadership support, vision availability, long-term plans, and policy availability, respectively. This is in line with the results of interviews with leaders, where the Rector and vice rector as deputy university leaders have issued policies related to the implementation of online learning at UNUSA. The main policy on which to base is the Rector's Circular No. 599 / UNUSA.B / Adm.I / III / 2020 regarding the implementation of the teaching and learning process for the even semester of the 2019/2020 academic year. This policy was then followed by other circular letters that were more specific regarding the implementation of practicum, fieldwork practices, and completion of final assignments. The policy is stated in the Rector's Circular No. 634 / UNUSA / 
Adm.I / IV / 2020. In terms of planning the implementation of online learning, the Deputy Chancellor for Academic Affairs revealed that since 2018, UNUSA has started implementing online learning with a blended learning scheme as preparation for the implementation of distance education, which will be implemented in the next few years.

Given the readiness category in this dimension is Ready, which requires improvement to implement it, then there are several things that must be improved in its implementation. This can be seen from the indicators that have a lower readiness score than others. The score is owned by work culture indicators and monitoring and evaluation mechanisms. Through a score of 3.97, work culture in implementing online learning must be improved again [20]. This is in accordance with interviews with leaders who stated that the implementation of online learning that is currently being carried out is not yet a habit but is still if needed. Therefore, in the future, lecturers and students need to design online learning that is more structured. Hopefully, the condition of full online learning that is currently being carried out due to the COVID-19 pandemic will make lecturers and students more accustomed to carrying out online learning. Meanwhile, on the monitoring and evaluation mechanism, periodic and comprehensive implementation needs to be improved. Given that currently, the existing mechanism is still not structured and only for the number of learning meetings. As stated by Bakar [20] that an organization must have a proper change management plan in order to successfully implement online learning

Table 5-Readiness level of Policy Dimension from the Student Perspective

\begin{tabular}{|c|c|c|c|c|c|}
\hline Dimension & Item Code & Item Description & Value & $\begin{array}{l}\text { Readiness } \\
\text { Score }\end{array}$ & $\begin{array}{l}\text { Readiness } \\
\text { Index }\end{array}$ \\
\hline \multirow{6}{*}{ Policy } & $\mathrm{P} 1$ & Vision & 3.72 & \multirow{6}{*}{3.63} & \multirow{6}{*}{$\begin{array}{c}\text { Ready, requires } \\
\text { improvement to } \\
\text { implement it }\end{array}$} \\
\hline & $\mathrm{P} 2$ & Long term plan & 3.43 & & \\
\hline & P3 & Regulation & 3.69 & & \\
\hline & $\mathrm{P} 4$ & Management support & 3.81 & & \\
\hline & P5 & Organizational culture & 3.46 & & \\
\hline & P6,P7,P8,P9 & Monitoring and evaluation mechanisms & 3.67 & & \\
\hline
\end{tabular}

Similar to the lecturer's perspective, based on Student's perspective, the readiness level of the policy dimension is also included in the Ready category, requiring improvement to implement it. Based on Table 5, it is known that the category obtained this dimension with a readiness score of 3.63. Basically, what UNUSA has prepared as a dimension of policy also applies to students. It's just that because student interaction with leaders does not occur directly but uses a cascading scheme at the faculty and study program levels, students do not fully understand the reasons for online learning. As stated by several students in the measurement instrument suggestions. The messages that are managerial and strategic are not fully accepted by students. Therefore, in the future, there is a need for a communication mechanism between university leaders and students to convey plans for implementing online learning more openly. So that the assumption that online learning is carried out on a coercive basis no longer appears. Not only that, but online learning culture also needs to be internalized by the leadership to all elements, both lecturers, students, and educational staff. This is in accordance with the conclusion of research conducted by [6] that leaders have a big role to play in forming a culture that is conducive to the implementation of online learning.

\subsection{Infrastructure Dimension}

The infrastructure dimension refers to the readiness of the organization in terms of providing infrastructure for implementing online learning [8]. This infrastructure includes hardware, software, and internet networks [9]. This dimension is measured by three indicators, namely the availability of hardware, software, and internet facilities. As stated by Akasalan and Law that, in any assessment of infrastructure readiness, the availability of hardware and internet connection must be included in the assessment instrument [21]. Meanwhile, the availability of software to measure the readiness of implementing online learning was stated by Akasalan et al [21]. The availability of this infrastructure is important, considering that the implementation of online learning is very dependent on the existence of the three devices.

Based on the results of the questionnaire processing, it is known that the infrastructure dimension readiness score is 4.22 for lecturers. Meanwhile, based on student responses, the readiness score on the infrastructure dimension is 3.69. The details of the readiness score for students are presented in Table 3. While the details of the readiness score for lecturers can be seen in Table 6. 
Table 6-Readiness level of Infrastructure Dimension from the Lecturer Perspective

\begin{tabular}{|c|c|c|c|c|c|}
\hline Dimension & Item Code & $\begin{array}{c}\text { Item } \\
\text { Description }\end{array}$ & Value & Readiness Score & Readiness Index \\
\hline \multirow{3}{*}{ Infrastructure } & I1 & Hardware & 4.22 & \multirow{3}{*}{4.22} & \multirow{3}{*}{$\begin{array}{l}\text { Ready, expressed } \\
\text { the good readiness } \\
\text { to implement } \\
\text { online learning }\end{array}$} \\
\hline & $\mathrm{I} 2$ & Software & 4.33 & & \\
\hline & I3 & $\begin{array}{l}\text { Internet } \\
\text { facilities }\end{array}$ & 4.11 & & \\
\hline
\end{tabular}

Based on Table 6, it is known that from a lecturer's perspective, the level of readiness in the infrastructure dimension is included in the Ready category, expressed the good readiness to implement online learning. This readiness index was obtained with a readiness score of 4.22. This result is not surprising considering that every lecturer at UNUSA already has hardware such as a laptop that can be used to carry out online learning. Not only that, based on the results of interviews with leaders, it was also known that the lecturers had been facilitated by a tablet. This means that if the lecturer independently does not have the hardware, they can still use the tablet facilities provided by the university. Meanwhile, the availability of software is also nothing to worry about. UNUSA already has several online learning applications, from e-sorogan to Academic SIM. Not only that, several open-source platforms that are already available on the internet can also be easily used by lecturers as needed. Another indicator in this dimension that has a score less than the limit for the Ready category expressed the good readiness to implement online learning is the availability of an internet network. Even though the score is already in the ready category, it still needs improvement in its implementation. Each lecturer is able to provide an internet network independently. However, in the future, the IT department needs to make a scheme to save internet quota, such as by using a VPN.

This is in accordance with what Akasalan and Law [21] say that internet connection readiness must be maintained in a stable manner. Online learning is very dependent on the quality of the internet network so that communication and interaction are not interrupted. In contrast to the lecturers' response, the level of infrastructure dimension readiness from the student perspective is included in the Ready category, requiring improvement to implement it. As seen in Table 7, the readiness score in this dimension is 3.69. As is known, the habit of students using campus internet facilities can no longer used during this pandemic. Students are required to carry out learning from their respective homes. This means that they are required to provide an internet network to be able to take part in online learning. One of the efforts that UNUSA has made to provide this internet network is to create a VPN. It is hoped that the internet quota that has been subscribed to by UNUSA can still be used by lecturers and students. Not only that, students who already have tablet facilities also get a monthly internet quota. It's just that what needs to be considered is the strength of the network in each student area is different. Apart from that, the provision of hardware also needs to be increased. Given that there are several departments that require hardware with certain specifications to carry out learning. Meanwhile, not all students have the necessary equipment. So that in the future, for the implementation of online learning, in addition to providing infrastructure, lecturers also need to find alternative software that can be accessed with hardware without special specifications. This is considering the statement from Akasalan and Law which states that the availability of the three infrastructures in a balanced manner determines the success of online learning [21].

Table 7-Readiness level of Infrastructure Dimension from the Student Perspective

\begin{tabular}{|c|c|c|c|c|c|}
\hline Dimension & $\begin{array}{l}\text { Item } \\
\text { Code }\end{array}$ & Item Description & Value & $\begin{array}{c}\text { Readiness } \\
\text { Score }\end{array}$ & Readiness Index \\
\hline \multirow{3}{*}{ Infrastructure } & I1 & Hardware & 3.66 & \multirow{3}{*}{3.69} & \multirow{3}{*}{$\begin{array}{l}\text { Ready, requires } \\
\text { improvement to } \\
\text { implement it }\end{array}$} \\
\hline & $\mathrm{I} 2$ & Software & 3.68 & & \\
\hline & I3 & Internet facilities & 3.74 & & \\
\hline
\end{tabular}

\subsection{Human Resources Dimension}

As mentioned by Chapnick at Jamal [19] that the human resource dimension refers to the availability and design of a human resource support system. The system in question includes the availability of programs or activities to prepare human resources [6]. This complements other indicators such as the competence and habits of lecturers and students in doing online learning. The indicators in this dimension are interrelated, where if the human resources competency is still low, a program is needed to carry out training or something else. This means that the human resource system support mechanism is adjusted to current competencies or skills.

The measurement results show that the level of readiness of the dimensions of human resources, both from the perspective of lecturers and students, is in the Ready category, requiring improvement to implement it. Each of them has a readiness score of 4.13 from the lecturer side and 3.51 from the student side. Details of measurement results on the dimensions of human resources can be seen in Table 8 and Table 9. 
Based on the lecturer's perspective, the existence of programs or activities to increase knowledge and abilities in the implementation of online learning obtained the highest readiness score. As shown in Table 8, the readiness score in that section reaches 4.38 , which means ready, it is good to implement online learning. This is in accordance with the efforts made by UNUSA, where programs related to the preparation of human resources include socialization on how to use technology and making tutorials in the form of videos. This UNUSA IT team provides this program learning is not just replacing face-to-face learning with technology. The ability development program provided by UNUSA is also related to how to prepare to teach and learning media. As stated by Surjono in Syamsul Jamal [19] that lecturers' ability must include the ability to operate technology and the ability to learn to teach. The second ability includes how lecturers interact in the teaching and learning process through technology, preparing evaluation mechanisms, and also interactive communication with students. Related to this, UNUSA has held several workshops for the creation of learning media that pay attention to aspects of pedagogy and andragogy.

Table 8-Readiness level of Human Resources Dimension from the Lecturer Perspective

\begin{tabular}{|c|c|c|c|c|c|}
\hline Dimension & $\begin{array}{l}\text { Item } \\
\text { Code }\end{array}$ & Item Description & Value & $\begin{array}{c}\text { Readiness } \\
\text { Score }\end{array}$ & Readiness Index \\
\hline \multirow{3}{*}{$\begin{array}{c}\text { Human } \\
\text { Resources }\end{array}$} & HR1 & $\begin{array}{l}\text { Program to increase } \\
\text { knowledge }\end{array}$ & 4.38 & \multirow{3}{*}{4.13} & \multirow{3}{*}{$\begin{array}{l}\text { Ready, requires } \\
\text { improvement to } \\
\text { implement it }\end{array}$} \\
\hline & HR2 & Skill & 4 & & \\
\hline & HR3 & $\begin{array}{l}\text { The habit of doing online } \\
\text { learning }\end{array}$ & 4 & & \\
\hline
\end{tabular}

From Student'snt's point of view, the level of readiness in the human resource dimension is in the same category as the lecturer. Although if seen in Table 8, the readiness score is lower. As explained in the policy dimension that online learning is still not a habit, the value on the HR3 (habit of doing online learning) is in the Not ready category, requiring preparation in several aspects. In terms of ability, students don't actually experience problems. It's just that getting used to online learning must be done.

Table 9-Readiness level of Human Resources Dimension from the Student Perspective

\begin{tabular}{|c|c|c|c|c|c|}
\hline Dimension & $\begin{array}{l}\text { Item } \\
\text { Code }\end{array}$ & Item Description & Value & Readiness Score & Readiness Index \\
\hline \multirow{3}{*}{$\begin{array}{c}\text { Human } \\
\text { Resources }\end{array}$} & HR1 & $\begin{array}{l}\text { Program to increase } \\
\text { knowledge }\end{array}$ & 3.77 & \multirow{3}{*}{3.51} & \multirow{3}{*}{$\begin{array}{c}\text { Ready, requires } \\
\text { improvement to } \\
\text { implement it }\end{array}$} \\
\hline & HR2 & Skill & 3.48 & & \\
\hline & HR3 & $\begin{array}{l}\text { A habit of doing online } \\
\text { learning }\end{array}$ & 3.26 & & \\
\hline
\end{tabular}

\subsection{Technology Dimension}

Online learning is learning that uses technology support. This concept means that the technology used must be able to support the teaching and learning process in an integrated manner [6], [16]. As stated by Surjono in Syamsul Jamal that in online learning, teachers not only upload material that can be accessed online by students but also evaluate, communicate, and manage other aspects of learning [19]. Based on this concept, the readiness of the technological dimension is measured by the availability of media, the presence of technology that integrates the teaching and learning process, and the flexibility in selecting the media used.

Based on the measurement results, the level of technological dimension readiness from the perspective of lecturers and students is included in different categories. Based on Table 10, it is known that the technological dimension readiness score from the perspective of a lecturer is 4.37. Meanwhile, based on Student's perspective, the technology dimension is categorized as Ready, requiring improvement to implement it with a readiness score of 3.74. The details of this score can be seen in Table 11. The flexibility in choosing online learning media gets the highest score on this dimension, which is 4.52. This is in accordance with the results of an interview with Munirul Huda as the UNUSA IT team. In the interview, it was stated that in online learning, lecturers were not required to use certain media. This means that lecturers are given the freedom to decide which media to use according to the needs and familiarity of the lecturers. Regarding the provision of media that integrates the teaching and learning process, from uploading material, interaction, to evaluation, the score is 4.3 . This means that the media provided is ready to be used to integrate the business process. This is important, as stated by Surjono in Syamsul Jamal [19] that online learning is not just uploading material that can be accessed online. 
Table 10-Readiness level of Technology Dimension from the Lecturer Perspective

\begin{tabular}{|c|c|c|c|c|c|}
\hline Dimension & Item Code & $\begin{array}{c}\text { Item } \\
\text { Description }\end{array}$ & Value & Readiness Score & Readiness Index \\
\hline \multirow{3}{*}{ Technology } & $\mathrm{T} 1$ & $\begin{array}{l}\text { Learning } \\
\text { media }\end{array}$ & 4.3 & \multirow{3}{*}{4.37} & \multirow{3}{*}{$\begin{array}{l}\text { Ready, expressed } \\
\text { the good readiness } \\
\text { to implement } \\
\text { online learning }\end{array}$} \\
\hline & $\mathrm{T} 2$ & $\begin{array}{l}\text { Integrated } \\
\text { technology }\end{array}$ & 4.3 & & \\
\hline & $\mathrm{T} 3$ & $\begin{array}{l}\text { Technological } \\
\text { flexibility }\end{array}$ & 4.52 & & \\
\hline
\end{tabular}

The results from the lecturer's perspective differ from Student's perspective. In Table 11, it can be seen that the readiness level of the technology dimension is in the Ready category, requiring improvement to implement it. Based on these results, some improvements that need to be made are the use of media agreed upon by the lecturers and students. This is important so that communication and interaction can be done optimally. Not only that, media that is integrated and involves student activity also needs to be improved. So far, recording attendance in online learning is still the burden of the lecturers. Meanwhile, students cannot independently register their attendance. Therefore, it is still prone to data inaccuracies. The online learning media used in the future must be able to accommodate the integration of the teaching and learning process starting from planning, implementation, evaluation, and administration.

Table 11-Readiness level of Technology Dimension from the Student Perspective

\begin{tabular}{|c|c|c|c|c|c|}
\hline Dimension & Item Code & $\begin{array}{c}\text { Item } \\
\text { Description }\end{array}$ & Value & Readiness Score & Readiness Index \\
\hline \multirow{3}{*}{ Technology } & $\mathrm{T} 1$ & $\begin{array}{c}\text { Learning } \\
\text { media }\end{array}$ & 3.64 & \multirow{3}{*}{3.74} & \multirow{3}{*}{$\begin{array}{c}\text { Ready, requires } \\
\text { improvement to } \\
\text { implement it }\end{array}$} \\
\hline & $\mathrm{T} 2$ & $\begin{array}{l}\text { Integrated } \\
\text { technology }\end{array}$ & 3.75 & & \\
\hline & $\mathrm{T} 3$ & $\begin{array}{l}\text { Technological } \\
\text { flexibility }\end{array}$ & 3.82 & & \\
\hline
\end{tabular}

\subsection{Financial Dimension}

Finance is another dimension that must be prepared to carry out online learning. The readiness of other dimensions requires the existence of this dimension. How not, in order to prepare an integrated technology, information technology investment is needed. Implementing training programs, providing infrastructure or policies also require financial support. In simple terms, the financial dimension relates to the size of the budget and the allocation process [6], [19]. Based on this, this dimension is measured by the availability of a budget and the provision of subsidies for the amount of the budget. Meanwhile, transparency of budget provision is used to measure the allocation process.

The measurement results show that both from the perspective of lecturers and students in the financial dimension, it is in the Ready category, requiring improvement to implement it. The readiness scores for each are 3.74 and 3.41 , as presented in Table 12 and Table 13. Regarding budget provision, UNUSA has made several IT investments coordinated by the IT team. Starting from purchasing a zoom license to setting up a VPN server. On the lecturer side, there are no financial constraints. This is because the salary received by the lecturer is still the same as when teaching face-to-face. It's just that transparency in the process of budget allocation and utilization needs to be improved.

Table 12-Readiness level of Financial Dimension from the Lecturer Perspective

\begin{tabular}{|c|c|c|c|c|c|}
\hline Dimension & $\begin{array}{l}\text { Item } \\
\text { Code }\end{array}$ & Item Description & Value & $\begin{array}{l}\text { Readiness } \\
\text { Score }\end{array}$ & Readiness Index \\
\hline \multirow{3}{*}{ Financial } & F1 & Availability of budget & 3.78 & \multirow{3}{*}{3.74} & \multirow{3}{*}{$\begin{array}{l}\text { Ready, requires } \\
\text { improvement to } \\
\text { implement it }\end{array}$} \\
\hline & $\mathrm{F} 2$ & The provision of subsidies & 3.83 & & \\
\hline & F3 & Transparency of budget provision & 3.61 & & \\
\hline
\end{tabular}

Meanwhile, students are the party who has to pay more to prepare infrastructure and other things to carry out online learning. The Student different economic conditions, the level of readiness from the student side in this dimension is lower than that of lecturers. As the party that pays for the tuition, students need transparency in the use of the budget during the implementation of online learning. Therefore, it is necessary to have regular reports related to IT 
investments that have been made. This communication is important to avoid misunderstandings in the future. Providing subsidies to students also needs to be considered. Because currently, students have received quota subsidies from the relevant ministries, then UNUSA needs to prepare a mechanism to optimize it. This is because the available quota is very limited for certain access only. Meanwhile, students' need for internet access varies. It is hoped that the VPN server investment that was previously carried out by UNUSA can be used again to optimize the quota obtained.

Table 13-Readiness level of Financial Dimension from the Student Perspective

\begin{tabular}{|c|c|c|c|c|c|}
\hline Dimension & Item Code & Item Description & Value & $\begin{array}{l}\text { Readiness } \\
\text { Score }\end{array}$ & $\begin{array}{l}\text { Readiness } \\
\text { Index }\end{array}$ \\
\hline \multirow{3}{*}{ Financial } & F1 & Availability of budget & 3.46 & \multirow{3}{*}{3.41} & \multirow{3}{*}{$\begin{array}{l}\text { Ready, requires } \\
\text { improvement to } \\
\text { implement it }\end{array}$} \\
\hline & $\mathrm{F} 2$ & The provision of subsidies & 3.40 & & \\
\hline & F3 & Transparency of budget provision & 3.39 & & \\
\hline
\end{tabular}

\subsection{Online Learning Readiness Level}

In addition to the scores and readiness indexes for each dimension, the measurement results also resulted in the overall online learning readiness level at UNUSA. Based on the detailed measurement results in Table 14, it is known that overall, the level of online learning readiness at UNUSA is in the Ready category, requiring improvement to implement it. This index is obtained based on a readiness score of 3.68. All dimensions are at the Ready level, requiring improvement to implement it.

Table 14- Summary of the Readiness Level

\begin{tabular}{ccl}
\hline Dimension & Readiness Score & \multicolumn{1}{c}{ Readiness Index } \\
\hline Policy & 3.72 & Ready, requires improvement to implement it \\
\hline Human Resources & 3.6 & Ready, requires improvement to implement it \\
\hline Infrastructure & 3.77 & Ready, requires improvement to implement it \\
\hline Technology & 3.84 & Ready, requires improvement to implement it \\
\hline Financial & 3.47 & Ready, requires improvement to implement it \\
\hline Overall & $\mathbf{3 . 6 8}$ & Ready, requires improvement to implement it \\
\hline
\end{tabular}

As seen in Fig 2, it is known that the readiness score in each dimension and overall has passed the discussion score to be said to be ready. The dimension with the most significant level of readiness is technology are dimensions of infrastructure, policy, human resources, and financial, respectively. Meanwhile, the dimension that has the smallest score is financial.

In the policy dimension, what needs to be improved in its implementation is the implementation and communication of various policies that have been made. Related to this, the role of leadership is needed, both as a decision-maker and as a messenger. The appropriateness of selecting communication media and defining sponsors of change is a strategy that must be a priority. In order to succeed in planning distance education in the future.

In the human resource dimension, increasing online learning skills must be done regularly. A resource support program evaluation mechanism should be in place. This is intended so that the training or workshop that is carried out does not end up as theory without being put into practice. Evaluation is important to do to see the effectiveness and efficiency of the program being carried out.

In the infrastructure and technology dimensions, improvements that must be made are related to optimizing existing equipment and facilities. The utilization of the quota provided must be optimized with the help of a scheme from the IT team. Meanwhile, technology readiness requires improvement in terms of integration support. This is important to simplify and document online learning.

Meanwhile, in the financial dimension, improvements that must be made are in terms of transparency in budget management. As something sensitive, UNUSA must be able to convince students that the facilities obtained will match what they paid for. Periodic reports can be used as an alternative to budget transparency. Clarity and transparency of budget management will help UNUSA to prepare improvements for other dimensions. 


\section{Online Learning Readiness Level}

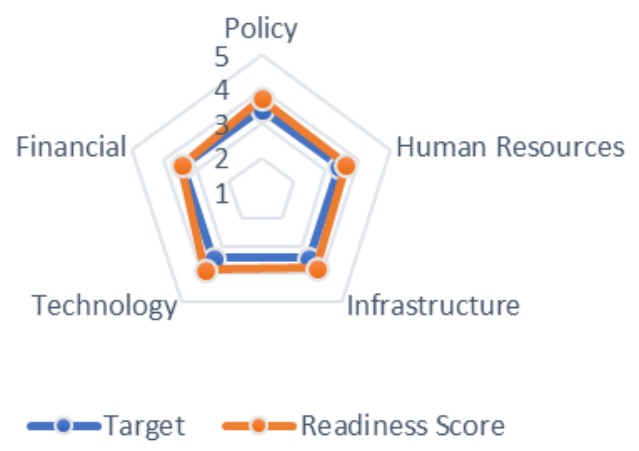

Fig. 2 Summary of the Readiness Score

\section{Conclusion}

Based on the measurement results, it is known that UNUSA's level of readiness in implementing online learning is in the Ready category, requiring improvement to implement it with a readiness score of 3.68. This level of readiness applies to readiness as a whole or for each dimension. The dimension with the highest score is technology, which is 3.84. Meanwhile, infrastructure and policy scored 3.77 and 3.72, respectively. Meanwhile, the human resources dimension has a readiness score of 3.6. In contrast, the dimension with the lowest score is the financial dimension. Considering that UNUSA's level of readiness is Ready, it requires improvement to implement it. It is necessary to increase its implementation. In the policy dimension, it is related to the implementation and communication of various policies that have been made with the support of the leadership. In the human resources dimension, it is necessary to program periodically by implementing an evaluation mechanism. In the infrastructure and technology dimensions, improvements that must be made are related to optimizing existing equipment and facilities. Meanwhile, in the financial dimension, improvements that must be made are in terms of transparency in budget management.

This research is still limited in identifying UNUSA readiness from the organizational side, which includes technical and non-technical matters. However, it has not reviewed the readiness of the lecturers and students in conducting learning interactions. Therefore, further research can examine the readiness for interaction between lecturers and students in the online learning process.

\section{Disclaimer}

The authors whose names are written certify that they have no conflict of interest.

\section{References}

[1] T. d. P. T. Kementerian Riset, "PJJ, E-Learning, \& Blended Learning," Kementerian Riset, Teknologi dan Pendidikan Tinggi, Jakarta, 2019.

[2] M. Asrori, "Warta Daerah," 4 Maret 2020. [Online]. Available: https://www.nu.or.id/post/read/118187/terapkan-e-sorogan--perkuliahan-di-UNUSA-tak-terganggu-viruscorona.

[3] UNUSA, "PDPT UNUSA," 15 Mei 2020. [Online]. Available: http://www.pdpt.UNUSA.ac.id. [Accessed 18 Mei 2020].

[4] L. Budairy, Interviewee, Press Release BEM FT UNUSA. [Interview]April 2ndil 2020.

[5] J. T. Suwarno, "Suarasurabaya.net," Suara Surabaya, 24 Maret 2020. [Online]. Available: https://www.suarasurabaya.net/kelanakota/2020/UNUSA-manfaatkan-e-sorogan-untuk-perkuliahan-ditengah-pandemi-covid-19/. [Accessed 1 April 2020].

[6] N. H. Waryanto and N. Insani, "The Readiness Level of Implementation E-Learning in Yogyakarta High Schools," Jurnal Pendidikan Matematika dan Sains, vol. 1, no. 2, pp. 117-124, 2013.

[7] E. King and R. Boyatt, "Exploring factors that influence adoption of e-learning within higher education," British Journal of Educational Technolog, pp. 1-9, 2014. 
[8] A. Saekow and D. Samson , "E-learning Readiness of Thailand's Universities Comparing to the USA's Cases," International Journal of e-Education, e-Business, e-Management and e-Learning, pp. 126-131, 2011.

[9] A. A. Mosa, M. Nazri bin Mahrin and R. Ibrrahim, "Technology Aspects of E-Learning Readiness in Higher Education: A Review of Literature," Computer and Information Science, vol. 9, no. 1, 2016.

[10] E. Rusdiana and A. Nugroho, "Respon pada Pembelajaran Daring bagi Mahasiswa Mata Kuliah Pengantar Hukum Indonesia," INTEGRALISTIK, pp. 1-12, 2020.

[11] F. Aldhafeedi and B. H. Khan, "Teachers and Students views on e-learning Readiness in Kuwait's Secondary Public Schools," Journal of Educational Technology System, vol. 45, no. 2, pp. 202-235, 2016.

[12] I. Tsani, R. Efendi and Sufirmansyah, "Evaluasi kesiapan lembaga pendidikan tinggi Islam dalam menghadapi era digital," Ta'dibuna, pp. 19-33, 2020.

[13] W. Nurcahyo, Y. Agustina and A. R. Efriadi, "Model Perancangan Pembelajaran Blended Mata Kuliah Keilmuan Akuntansi Di ITB-AD Jakarta," Jtp : Jurnal Teknologi Pendidikan, pp. 179-199, 2019.

[14] Borotis and Poulymenakou, "E-Learning Readiness Components: Key Issues to Consider Before Adopting ELearning Interventions,January 8thry 2008. [Online]. [AccesseApril 20thil 2020].

[15] J. S. H, "Analisis Kesiapan E-Learning Telkom University Dengan Menggunakan E-Learning Readiness (ELR) Model (Studi Kasus I-Caring)," in e-Proceeding of Engineering Vol.2 No.1, 2015.

[16] I. Purwandani, "Analisa Tingkat Kesiapan E-Learning (E-Learning Readiness) Studi Kasus: AMIK Bina Sarana Informatika Jakarta," Jurnal Bianglala Indonesia, vol. 5, no. 2, pp. 102-107, 2017.

[17] C. H. Aydm, "Measuring Readiness for e-Learning: Reflection from Emerging Country," Educational Technology and Society Journal, vol. 8, no. 4, pp. 244-257, 2005.

[18] R. Pala, "Studi Kesiapan Pemerintah Kabupaten Maros dalam Pengimplementasian Sistem Informasi Kehadiran Pegawai Berbasis Elektronik," Pekommas, vol 16, no. 3, pp., pp. 169-176, Dec. 2013.

[19] S. Jamal, "Analysis of E-Learning Readiness During the Covid-19 Pandemic at SMK Negeri 1 Tambelang," Jurnal Nalar Pendidikan, vol. 8, no. 1, pp. 16-22, 2020.

[20] N. A. A. Bakar, Z. Deraman, M. F. Tarmiji, R. Yusoff and N. Kama, "Workplace Digitalization in Public Sector Organization Towards Operational Effectiveness: Current Landscape, Issues and Challenges," International Journal of Innovation in Enterprise Systems (IJIES), vol. 4, no. 1, pp. 78-83, 2020.

[21] D. Akaslan and E. Law, "Measuring Teacher's Readiness for E-Learning in Higher Education Institutions Associated With The Subject of Electricity in Turkey," in Global Engineering Education Conference, 2011. 